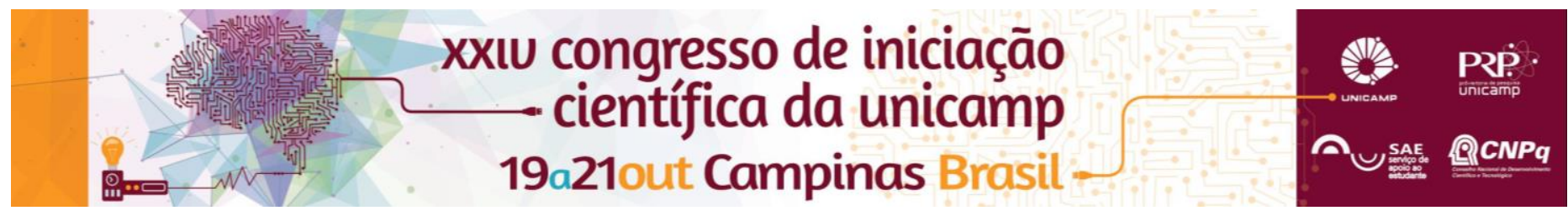

\title{
ACUMULAÇÃO INTERNA NA COLONIA PORTUGUESA NA AMÉRICA E DINAMISMO DO MERCADO INTERNO: DOIS ASPECTOS DA FORMAÇÃO ECONÔMICA BRASILEIRA.
}

\author{
Nathália Parras de Lima*. Orientador: Carlos Alberto Cordovano Vieira.
}

\begin{abstract}
Resumo
O presente trabalho irá expor uma revisão de duas visões diversas e até certo ponto contrapostas, referentes a existência e escala da acumulação de capital e mercado interno da América portuguesa. A partir destes dois elementos busca-se uma análise da formação econômica brasileira a partir da análise da sua economia colonial e seus principais aspectos. Para esta revisão bibliográfica utilizamos das obras "Portugal e Brasil na Crise do Antigo Sistema Colonial" de Fernando Novais (1989) e "Arcaísmo como Projeto" de João Fragoso e Manolo Florentino (2001).
\end{abstract}

\section{Palavras-chave:}

Mercado interno, Acumulação interna, Economia colonial.

\section{Introdução}

Ao pensar na formação econômica do Brasil torna-se necessário refletir acerca das condições econômicas existentes ainda no período colonial. Este trabalho, portanto, buscou posições diferentes de grandes autores brasileiros a respeito da acumulação interna e do dinamismo do mercado no período colonial. Tais visões contrapostas podem ser encontradas nos textos de Fernando Novais, "Brasil e Portugal na crise do Antigo Sistema Colonial (1777-1808) ${ }^{1}$ e no texto de João Fragoso e Manolo Florentino "Arcaísmo como Projeto"(2001)2. A partir da análise desde e de outros autores fundamentais para a compreensão da formação econômica brasileira como Celso Furtado e Caia Prado Junior, busca-se uma reflexão a cerca das principais características tanto da colônia quando da metrópole, o que permite analisar a estruturação da econômica da colônia portuguesa na América, a partir do Antigo Sistema Colonial, do tráfico negreiro, das características políticas-econômicas de Portugal e das características político-sociais que se conformam na colônia.

\section{Resultados e Discussão}

A partir da revisão bibliografia, pode-se estabelecer a periodização deste trabalho entre os séculos XVI e XIX, considerando como contexto histórico-econômico a transição do sistema feudal para o sistema capitalista. A importância desde contexto, é evidenciada tanto no texto de Novais (1989), que irá tratar do papel do Antigo Sistema Colonial na transição do feudalismo para capitalismo, como também no texto de Fragoso e Florentino (2001), dado que, por se tratar de um período de transição existe uma heterogeneidade evidente do grau de transição entre os países europeus, evidenciando que ao mesmo tempo que na Inglaterra, no século XVIII já existiam características mais sólidas do sistema capitalista, em Portugal, a estrutura política e social era claramente do Antigo Regime, com grande controle por parte da aristocracia e da Igreja, um Estado Absolutista que possuía o controle do comércio, uma sociedade em grande medida arcaica, pautada em privilégios. Tais características são fundamentais na tese desses autores, pois o argumento da existência tanto de um mercado interno dinâmico, tanto da acumulação interna da colônia perpassa pela autonomia dos colonos instalados permanentemente na colônia, que reproduzem a sociedade metropolitana, garantindo sua autonomia a partir de monopólios e privilégios alcançados em âmbito político.

Novais (1989), por outro lado, apresenta uma visão distinta, não considerando a existência de acumulação interna ou de mercado interno dinâmico de proporções relevantes do período colonial. Destaca-se que para o autor o Antigo Sistema Colonial está em contexto de formação do capitalismo na Europa e, desta forma a colônia tem como principal utilidade promover a acumulação primitiva da metrópole. Pode-se destacar que tanto o exclusivismo metropolitano, quanto o tráfico negreiro, são elementos que o excedente gerado na colônia seja amplamente apropriado pela metrópole. Por exclusivismo metropolitano, entende-se que o comércio era realizado majoritariamente por comerciantes da metrópole, o que inibiria a retenção de capital dentro da colônia. Quanto ao tráfico negreiro, o autor argumenta que este além de gerar receitas vultosas a metrópole, por intermediar as negociações com a colônia, ainda inibiria a formação de produtores independentes.

\section{Conclusões}

Ao se tratar da formação econômica de um país é preciso ter em mente que, para além do contexto histórico econômico mais amplo, existem características específicas de cada sociedade ali estruturada. Ao contrapor a visão de dois grandes autores sobre a acumulação interna e o dinamismo no mercado interno ainda no período colonial, não se buscou uma verdade absoluta, mas sim, entender os principais argumentos que norteiam esse debate a cerca da formação econômica brasileira.

\section{Agradecimentos}

Agradeço ao SAE Unicamp e ao CNPq pelo apoio na realização deste estudo.

Agradeço imensamente ao meu orientador Carlos Alberto Cordovano Vieira, pela oportunidade de participar deste debate acerca da formação econômica brasileira.

${ }^{1}$ FRAGOSO, J., FLORENTINO M. Arcaísmo como projeto: mercado atlântico, sociedade agrária e elite mercantil em uma economia colonial tardia, Rio de Janeiro: Civilização Brasileira, 2001

2 NOVAIS, Fernando. Portugal e Brasil na Crise do Antigo Sistema Colonial (1777-1808). São Paulo: Editora Hucitec, $5^{\circ}$ edição, 1989 